\title{
COMPARISON SHOPPING AGENTS AND CZECH ONLINE CUSTOMERS' SHOPPING BEHAVIOUR
}

\author{
Michal PILIK ${ }^{1}$, Petr KLIMEK ${ }^{2}$, Eva JURICKOVA ${ }^{3}$, Premysl PALKA ${ }^{4}$
}

\begin{abstract}
The internet has changed the lifestyles and shopping behaviours of customers. Online purchasing enables people to obtain information about products and services provided more effectively and easily, with the result that home shopping has become ordinary and usual. This paper presents part of a research focusing on online shopping customers' behaviour in the Czech Republic. The article pertains to comparison shopping agents (CPAs), a tool which provides information to customers and helps find the best offer. The research was conducted on the basis of an online questionnaire available on an internet web page. The main results confirmed a dependency between online purchasing and the use of shopping agents, which are very popular in the Czech Republic. Almost two-thirds of online shoppers use CPAs when they engage in internet shopping. The final part of the paper addresses references and customers' reviews as an important factor for the selection of online retailer.
\end{abstract}

\section{KEY WORDS}

e-commerce, comparison shopping agent, customer review, references

\section{JEL CLASSIFICATION}

M31, L81

\section{INTRODUCTION}

The internet has become one of the most popular shopping channels and its usage has increased in the past few years. InternetWorldStats (2016) show that there are over 604 million internet users in Europe and overall there is $73.5 \%$ internet penetration. According to Eurostat (2016) $65 \%$ of European internet users shopped online in 2015. Almost two-thirds of internet users in the EU made purchases during the same time. The segment of online sales of goods in Europe is expected to

\footnotetext{
${ }^{1}$ Michal Pilik, doc., Ing., Ph.D., Department of Management and Marketing, Faculty of Management and Economics, Tomas Bata University in Zlín, Mostni 5139, 760 01, Zlin, Czech Republic, Email: pilik@ fame.utb.cz

${ }^{2}$ Petr Klimek, doc., Ing., Ph.D., Department of Statistics and Quantitative Methods, Faculty of Management and Economics, Tomas Bata University in Zlín, Mostni 5139, 760 01, Zlin, Czech Republic, Email: klimek@ fame.utb.cz ${ }^{3}$ Eva Jurickova, Ing., Ph.D., Department of Industrial Engineering and Information Systems, Faculty of Management and Economics, Tomas Bata University in Zlín, Mostni 5139, 760 01, Zlin, Czech Republic, Email: jurickova@fame.utb.cz

${ }^{4}$ Premysl Palka, Ing., Ph.D., Department of Finance and Accounting, Faculty of Management and Economics, Tomas Bata University in Zlín, Mostni 5139, 760 01, Zlin, Czech Republic, Email: ppalka@fame.utb.cz
} 
reach EUR 509.9 billion in 2016 (Ecommerce News, 2016). The e-commerce turnover in Europe increased by $13.3 \%$ to reach EUR 455.3 billion in 2015 .

Internet shopping agents plays a role as a tool for comparing the prices of items from different sources in order to find the best deal (Hajaj, Hazon, \& Sarne, 2015). Doorenbos, Etzioni, and Weld (1997) defined the capabilities of a sophisticated shopping assistant to include the following: 1) helping the user decide what product to buy, e.g. by listing what products of a certain type are available, 2) finding specifications and reviews of them, 3) making recommendations, 4) comparison shopping for the best price for the desired product, 5) monitoring 'What's new' lists and other sources to discover new relevant online information sources, 6) and watching for special offers and discounts. Comparison shopping agents (CPAs) as an intermediary facilitate shopping for potential customers and provide information to e-shoppers.

The aim of the paper is to examine a role of comparison shopping agents in Czech customers' shopping behaviour. The contributions of the paper are twofold. To begin, we follow previous studies that have pursued this topic to describe e-commerce on B2C markets and available comparison shopping agents in the Czech Republic. Than we analyse the usage of CPAs in the Czech market and the influence of customers' reviews and references on consumers' choices of eshops and online purchasing process.

The paper is organised as follows. In section 2 we provide a basic review of the literature and the theoretical background to the topic. Section 3 explains the methodology of the research and data collection. The main results are presented and discussed in section 4. Section 5 highlights the main conclusions of the paper.

\section{LITERATURE REVIEW}

E-commerce has led to dramatic changes and evolutions in commercial affairs. That is, e-commerce has led to variations and changes in buying and selling products and items and has improved the relations and communication between the customers and suppliers (Choshin \& Ghaffari, 2017). Anvari and Norouzi (2016) state the internet is dramatically expanding opportunities for businessto-business and business-to-consumer e-commerce transactions across borders; online shopping is growing year by year. Go Globe (2016) presents the estimated amount spent on online shopping by Czech e-shoppers in 2015 as 81 billion CZK compared to 67 billion in 2014. At least $42 \%$ of Czech shoppers shopped online in 2015 and online purchases account for $8.1 \%$ of total retail sales in the Czech Republic.

The study of Huang and Tsai (2011) mentions that comparison shopping agents are becoming more and more important as the number of e-tailers is increasing. CPAs help potential shoppers to orientate between various e-shops not only in price issues, but also in offers of particular retailers comparing advantages and disadvantages of individual purchases possibilities. Czech customers prefer good prices for products or services (Pilík \& Juřičková, 2016) but have the option to compare further factors influencing the purchase such as convenience, terms of delivery, service, etc. In this context, the CPA can be considered an effective tool to compare merchandise in clearly defined parameters.

Comparison shopping agents are one of the most important sources of online shops' revenues. We can compare CPAs due to their size and the number of real or potential users. According to NetMonitor (2016) heureka.cz is the most visited CPA in the Czech Republic, followed by zbozi.cz a srovname.cz. 


\section{RESEARCH AIM, METHODOLOGY AND DATA USED}

The purpose of this paper is to describe online shopping behaviour in the Czech Republic and identify the influence of shopping agents on the purchasing process. The research was conducted in 2015 on the basis of a survey of online purchasing conditions and factors impacting the online buying process. The study was implemented by using a questionnaire focusing on the research area presented on a website. The sample consisted of 1,601 respondents and the questionnaire included 40 questions. The first questions focused on the respondents and related to their age, gender, education and internet literacy. The second part of the research was connected to the online shopping behaviour of the internet customers. This article presents part of the results obtained.

As can be seen in Table 1, the sample included 962 women (60.1\%) and 639 men (39.9\%). More than $65 \%$ of respondents came from the category millennials (ages 18-34). The research included university-educated respondents $(48.2 \%)$ and $63 \%$ of participants were common internet users.

\section{Table 1 Sample demographics}

\begin{tabular}{|c|c|c|c|}
\hline & & $\mathrm{N}$ & $\%$ \\
\hline Gender & $\begin{array}{l}\text { Male } \\
\text { Female }\end{array}$ & $\begin{array}{l}639 \\
962\end{array}$ & $\begin{array}{l}39.9 \\
60.1\end{array}$ \\
\hline Age & $\begin{array}{l}16-24 \\
25-34 \\
35-44 \\
45-54 \\
55-64 \\
65+\end{array}$ & $\begin{array}{l}563 \\
482 \\
239 \\
184 \\
85 \\
48 \\
\end{array}$ & $\begin{array}{l}35.2 \\
30.1 \\
14.9 \\
11.5 \\
5.3 \\
3\end{array}$ \\
\hline $\begin{array}{l}\text { Level of } \\
\text { Study }\end{array}$ & $\begin{array}{l}\text { Primary } \\
\text { education } \\
\text { Secondary } \\
\text { school } \\
\text { without } \\
\text { graduation } \\
\text { Secondary } \\
\text { school with } \\
\text { graduation } \\
\text { University } \\
\text { degree }\end{array}$ & $\begin{array}{l}613 \\
771\end{array}$ & 38.3 \\
\hline $\begin{array}{ll}\text { Level of } \\
\text { Internet } \\
\text { Literacy }\end{array}$ & $\begin{array}{l}\text { Beginner } \\
\text { Common user } \\
\text { Advanced } \\
\text { user } \\
\text { Professional } \\
\end{array}$ & $\begin{array}{l}182 \\
1008 \\
358 \\
53 \\
\end{array}$ & $\begin{array}{l}11.4 \\
63 \\
22.4 \\
3.3 \\
\end{array}$ \\
\hline
\end{tabular}

(Source: own research)

Based on the theoretical framework which was outlined in the previous part of paper, the following hypotheses were set prior to the research:

H1: $\quad$ Czech customers use comparison shopping agents when shopping online on the internet. 
H2: References and customers' reviews are very important factors when choosing an e-shop.

Pearson's correlation coefficient was used to measure the correlation between variables. The pvalue considered significant was the $0.05 \%$ level. If the p-value is lower than the significance level, we reject the null hypothesis that there is no association between variables. The statistical package for the social sciences (SPSS) was used for the calculations.

\section{RESULTS AND DISCUSSION}

\subsection{Basics of online shopping in the Czech Republic}

According to the Czech Statistical Office (2015) more than 60\% of millennials are shopping on the internet. Based on the results of our research, almost 55\% of research participants shop for products or services online on an irregular basis. $12.5 \%$ respondents do not purchase on the internet, but prefer traditional brick-and-mortar shops (presented in Figure 1).

\section{Figure 1 Internet buying in the Czech Republic}

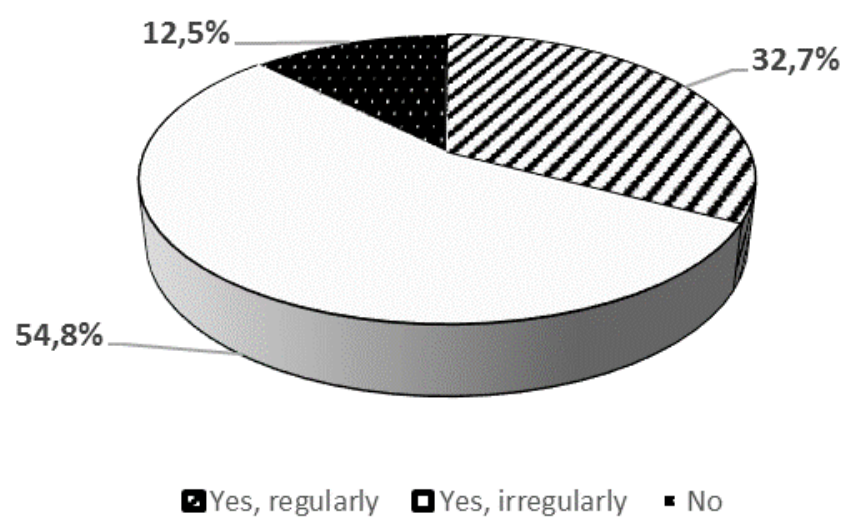

(Source: own research)

Eurostat (2016) states that more than two-thirds of European internet users shopped online in 2015. The share of e-buyers is growing with the highest proportion in the 16-54 age bracket (over 68\% in each category). The European research shows the $25-54$ age group shops online regularly (14\% of respondents shopped online more than 10 times in the previous 3 months), the second group of eshoppers is surprisingly the 55-74 age group (10\% of participants).

\subsection{Comparison shopping agents}

Nowadays internet agents not only have a function of comparing the prices of competitive online shops, but also of offering advice about products, services and other information that is given by real customers and sellers. This new role marks them as 'comparison shopping agents' that try to help customers find the best offer.

The main role of shopping agents is to make shopping easier and help to navigate amidst present offers of e-shops, as mentioned below. Table 2 presents shopping agents in the Czech Republic compared to their size. According to NetMonitor (2016), heureka.cz is the leader in a group of CPAs (presented in Table 2). This agent is followed by zbozi.cz and srovnanicen.cz. The data are based on a number of real users of the CPAs without affiliated agents (heureka.cz without 
srovnani.cz, nejlepsiceny.cz and seznamzbozi.cz) over the period of the second half of 2016, specifically till the end of October 2016.

Table 2 Comparison shopping agents in the Czech Republic (in \% of real users)

\begin{tabular}{|l|c|c|}
\hline & 2015 & $07-10 / 2016$ \\
\hline heureka.cz & $24.28 \%$ & $19.77 \%$ \\
zbozi.cz & $15.55 \%$ & $12.93 \%$ \\
srovnanicen.cz & $3.45 \%$ & $5.41 \%$ \\
\hline
\end{tabular}

(Source: own calculations based on NetMonitor, 2016)

The regularity of CPA usage in a comparison between regular and irregular e-shoppers is shown in Table 3.

\section{Table 3 Usage of shopping agents in the Czech Republic}

\begin{tabular}{|l|c|c|c|}
\hline & $\begin{array}{c}\text { Regular online } \\
\text { customers }\end{array}$ & $\begin{array}{c}\text { Irregular online } \\
\text { customers }\end{array}$ & $\begin{array}{c}\text { Total regular and } \\
\text { irregular online } \\
\text { customers }\end{array}$ \\
\hline Yes, regularly & 60.9 & 42.6 & 49.9 \\
Yes, irregularly & 27.9 & 36.7 & 33.2 \\
No & 11.2 & 20.7 & 16.9 \\
\hline
\end{tabular}

(Source: own research)

Almost $50 \%$ of e-shoppers use shopping agents regularly. It is clear that $83 \%$ of online customers use shopping agents because of the help in navigating the extensive offers of the e-shops. Based on the results of this research, we can state that Czech customers use shopping agents as an instrument for effective shopping without any dependency on regularity of purchases. Thus, hypothesis H1 was confirmed.

The purpose of the hypothesis H1 was to confirm a dependency between online purchasing and the use of shopping agents as a tool for the comparison of e-shops. The data presented in Table 4 were analysed using a chi-square test, which examined the relationship between the defined variables. The p-value is compared with the standard 5\% significance level. If the p-value is lower than the standard significance level $\alpha=0.05$, we reject the null hypothesis of the independence of variables.

\section{Table 4 Chi-squared test}

\begin{tabular}{|l|c|c|c|}
\hline & Value & df & $\begin{array}{c}\text { Asymp. Sig. } \\
\text { (2-sided) }\end{array}$ \\
\hline Pearson Chi-Square & 46.539 & 2 & $7.837 \mathrm{E}-11$ \\
\hline Likelihood Ratio & 47.230 & 2 & $5.549 \mathrm{E}-11$ \\
\hline $\begin{array}{l}\text { Linear-by-Linear } \\
\text { Association }\end{array}$ & 44.587 & 1 & $2.433 \mathrm{E}-11$ \\
\hline
\end{tabular}

(Source: own research) 
Since the p-value $(7,837 \mathrm{E}-11)$ is smaller than the standard significance level $\alpha=0.05$, we reject the null hypothesis $\mathrm{H} 0$ of independence between online shopping and the use of shopping agents when conducting online purchasing. The hypothesis H1 was statistically confirmed; the dependency of these two variables exists.

\subsection{Customer reviews}

Customers' reviews are important criteria for the selection of online retailers. In addition to these factors, Chaffey (2006) defines more key areas defined by e-shoppers: logistics, trust and security, on-time delivery, merchandise in stock, convenience and service. Czech customers prefer online shops with positive customer reviews, clear and easy menu navigation and a focus on terms of delivery. It is obvious that customers who are not able to find the required information or product/service in a short time are leaving e-shop very quickly. Figure 2 presents the criteria of customers when choosing an online shop.

\section{Figure 2 Criteria for online shop preference (in absolute numbers)}

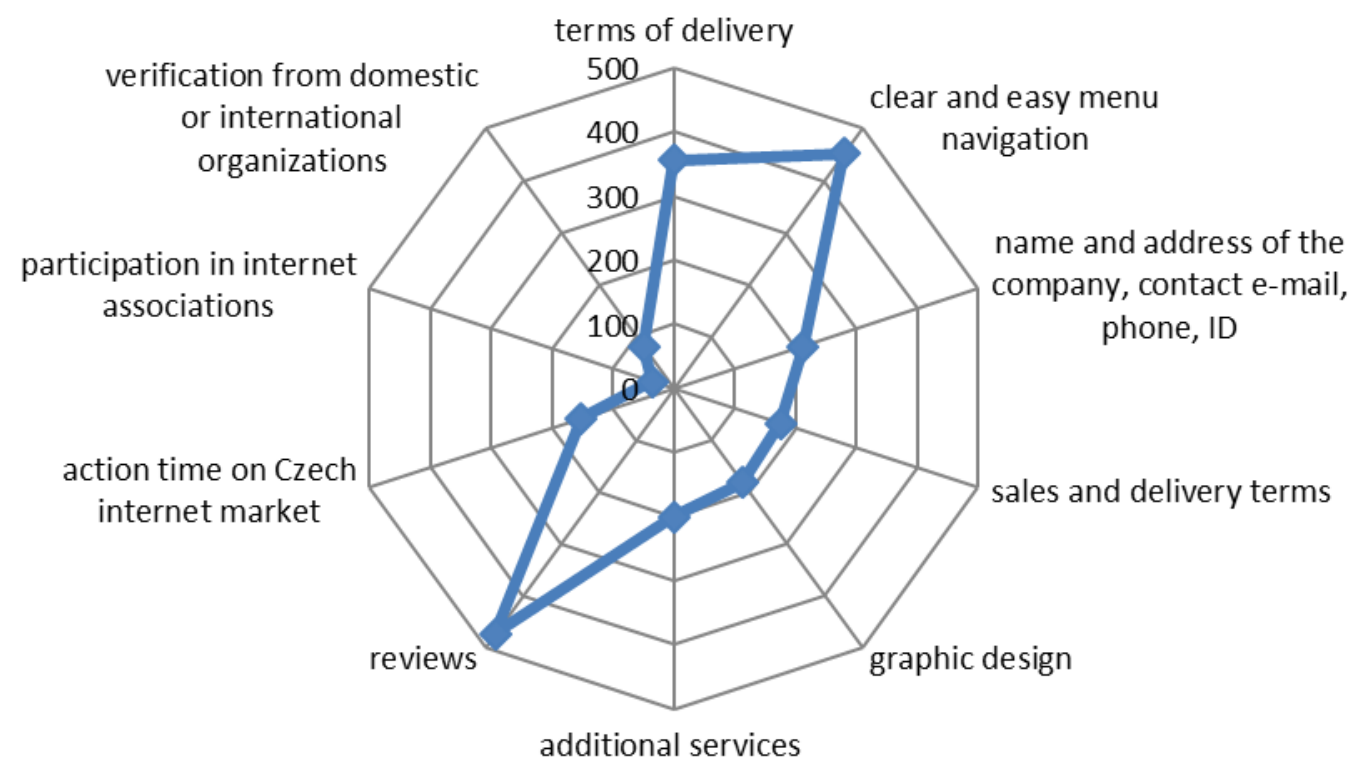

(Source: own research)

Customers shop online because they do not want to waste time visiting brick-and-mortar shop and they need merchandise available as soon as possible or readily available. This is one of the reasons customers use reviews as a key factor influencing the selection of e-shop (marked by 473 participants of all age categories). Clear menu navigation was identified as the second most important factor (in the answers of 453 respondents), and terms of delivery are very important for 355 of the e-shoppers. Thus, hypothesis H2 was confirmed. We regard references and customers' reviews as important factors when customers choosing an e-shop. 


\section{CONCLUSIONS}

This paper has presented a part of a complex research that focused on the problem of comparison shopping agents (CPAs) and their utilisation in online purchasing in the Czech Republic. The results of the research show regular usage of CPAs when shopping online and definitely confirmed a dependency between these two variables. The last part of the paper pursues the topic of customers' reviews and the relevance of this factor in e-shop selection.

\section{ACKNOWLEDGEMENT}

The authors would like to thank the RVO project, "Modelling of effective production and administration processes parameters in industrial companies based on concept Industry 4.0", undertaken by the Department of Industrial Engineering and Information Systems, Faculty of Management and Economics, Tomas Bata University in Zlín.

\section{REFERENCES}

Anvari, R. D., \& Norouzi, D. (2016). The impact of E-commerce and R\&D on economic development in some selected countries. Procedia-Social and Behavioral Sciences, 229, 354-362. doi: $10.1016 /$ j.sbspro.2016.07.146

Chaffey, D. (2006). Internet marketing: Strategy, implementation and practice. Harlow: Financial Times Prentice Hall.

Choshin, M., \& Ghaffari, A. (2017). An investigation of the impact of effective factors on the success of e-commerce in small-and medium-sized companies. Computers in Human Behavior, 66, 67-74. doi: 10.1016/j.chb.2016.09.026

Czech Statistical Office. (2015). Jednotlivci v České republice nakupující přes internet v letech $2005 a \check{z}$ 2015. Oficiální stránky Českého statistického úruadu. Retrieved from https://www.czso.cz/documents/10180/20568879/062004-1549.pdf/46d97789-a0b1-425d-b3cca9b18c6ffb27?version $=1.0$

Doorenbos, R. B., Etzioni, O., \& Weld, D. S. (1997, February). A scalable comparison-shopping agent for the world-wide web. In Proceedings of the First International Conference on Autonomous Agents (pp. 39-48). New York: ACM.

E-commerce News. (2016). Ecommerce in Europe to reach E509.9 billion in 2016. Retrieved August 02, 2016, from http://ecommercenews.eu/ecommerce-europe-reach-e509-9-billion-2016

Eurostat. (2016). E-commerce statistics for individuals. $65 \%$ of internet users in the EU shopped online in 2015. Retrieved from http://ec.europa.eu/eurostat/statistics-explained/index.php/Ecommerce_statistics_for_individuals

Go Globe. (2016). E-commerce in Czech Republic - statistics and trends. Retrieved from http://www.go-globe.com/blog/e-commerce-czech-republic/

Hajaj, C., Hazon, N., \& Sarne, D. (2015). Improving comparison shopping agents' competence through selective price disclosure. Electronic Commerce Research and Applications, 14(6), 563581. doi: 10.1016/j.elerap.2015.08.006 
Huang, S. L., \& Tsai, Y. H. (2011). Designing a cross-language comparison-shopping agent. Decision Support Systems, 50(2), 428-438. doi:10.1016/j.dss.2010.10.004.

InternetWorldStats (2016). Europe internet usage stats Facebook subscribers and population statistics. Retrieved from http://www.internetworldstats.com/stats4.htm

NetMonitor. (2016). Online data. E-commerce-prodej. Retrieved from http://www.netmonitor.cz/online-data-ola

Pilík, M., \& Juřičková, E. (2016). Trust and security as significant factors influencing online buying behaviour in the Czech Republic. Economics Management Innovation, 8(2), 31-44. 